\title{
Landowners in Colonial Peru
}

Latin American Monographs, No. 61 Institute of Latin American Studies The University of Texas at Austin 
THIS PAGE INTENTIONALLY LEFT BLANK 


\section{Landowners in Colonial Peru}

By Keith A. Davies

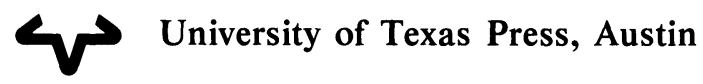




\section{Library of Congress Cataloging in Publication Data}

Davies, Keith A.

Landowners in colonial Peru

(Latin American monographs/Institute of Latin American Studies, the University of Texas at Austin; no. 61)

Includes bibliographical references and index.

1.Land tenure-Peru-Arequipa (Dept.)--History.

I. Title. II. Series: Latin American monographs (University of Texas at Austin. Institute of Latin American Studies); no. 61. HD559.A73D38 $1984 \quad 333.3$ '0985132 $83-16749$

ISBN 0-292-74639-3

Copyright $(\mathbb{C} 1984$ by the University of Texas Press All rights reserved Printed in the United States of America

First Edition, 1984

Requests for permission to reproduce material from this work should be sent to:

Permissions

University of Texas Press

P.O. Box 7819

Austin, Texas 78713

ISBN 978-0-292-76622-8 (library e-book)

ISBN 978-0-292-76623-5 (individual e-book) 
To my mother and father 
THIS PAGE INTENTIONALLY LEFT BLANK 